\title{
CAVES AND KARST AQUIFER DRAINAGE OF SUPRAMONTE (SARDINIA, ITALY): A REVIEW
}

\author{
JAME IN KRAŠKI ODTOK V GOROVJU SUPRAMONTE \\ (SARDINIJA, ITALIJA): PREGLED
}

\author{
Salvatore CABRAS ${ }^{1,2}$, Jo DE WAELE ${ }^{2,3}$ \& Laura SANNA ${ }^{2,4}$
}

\begin{abstract}
UDC 556.34(450.88)

Salvatore Cabras, Jo De Waele \& Laura Sanna: Caves and karst aquifer drainage of Supramonte (Sardinia, Italy): A review.

Supramonte is one of the biggest and interesting karst areas of Sardinia (Italy), hosting extensive cave systems explored since the 50s. Early cavers and scientists have carried out some dye tests, but hydrogeological research was hindered by lack of accessible underground rivers. A complex subterranean river system has been discovered in the past decade enabling to organise several new tracer tests. The history of cave explorations, the morphology and hydrology of the systems and the dye tracing experiments are reviewed in this paper in order to give an updated view on hydrogeology of this important karst area.

Keywords: Speleology, underground drainage, cave morphology and hydrology, hydrogeology, dye tracer tests.
\end{abstract}

Izvleček

UDK 556.34(450.88)

Salvatore Cabras, Jo De Waele \& Laura Sanna: Jame in kraški odtok v gorovju Supramonte (Sardinija, Italija): Pregled.

Supramonte je eno največjih in najzanimivejših kraških regij na Sardiniji. V zadnjih petdesetih letih so v gorovju raziskali več velikih jamskih sistemov. Že prvi jamarji in raziskovalci so naredili nekaj sledilnih poskusov $\mathrm{z}$ barvanjem, vendar takrat večjih podzemnih tokov še niso poznali. $V$ zadnjem desetletju so odkrili večji podzemni vodni system, ki je omogočal izvedbo novih sledilnih poskusov. $\mathrm{V}$ članku pregledno opišemo zgodovino speleoloških, morfoloških in hidroloških raziskav območja, posebno pozornost pa namenjamo rezultatom sledilnih poskusov. Namen članka je celostno prikazati razultate novejših raziskav $\mathrm{v}$ tem pomembnem kraškem masivu.

Ključne besede: Speleologija, podzemni odtok, jamska morfologija in hidrologija, hidrogeologija, sledilni poskusi.

\section{INTRODUCTION}

The understanding of karst hydrology has improved a lot in the past decades and several reviews (Bakalowicz 2005; Pulido Bosch 2001; White 2002) or state of the art publications (Andreo 2008; Goldscheider \& Drew 2007) have been printed recently.

Karst aquifers show exceptional heterogeneous permeability distribution with water moving along intergranular pores, more or less open fractures and con- duits (Gabrovšek et al. 2004). This makes karst aquifers extremely difficult to model (Gabrovšek et al. 2005), and vulnerability assessment can be a complicated task (Daly et al. 2002; Perrin et al. 2004).

If underground drainage routes are not accessible, the karst aquifer can be studied by monitoring at the springs. Especially the analysis of hydraulic (Labat et al. 2002) and physico-chemical response of a spring to re-

\footnotetext{
${ }^{1}$ Gruppo Archeo Speleo Ambientale Urzulei

${ }^{2}$ Associazione Speleologica Progetto Supramonte

${ }^{3}$ Dipartimento di Scienze della Terra e Geologico-Ambientali, University of Bologna, e-mail jo.dewaele@unibo it

${ }^{4}$ Gruppo Speleo Ambientale Sassari

Received/Prejeto: 19.8.2008
} 
charge events (Birk et al. 2004; Desmarais and Rojstaczer, 2002) is an extremely useful tool in characterising the karst aquifer. These investigations can give an idea of the structure of a karst system, e.g. whether it is organised in a well-developed underground drainage or recharged by water flowing in a fissure network. The insight on hydrodynamic behaviour of underground water flows can be studied directly if caves with subterranean rivers are accessible (Prelovšek et al. 2008).

Determining karst groundwater divides is not a straightforward task. The boundaries between adjacent karst groundwater basins can vary in different hydrological conditions (e.g. floods) or because of piracies. Dye tracing experiments can determine connections between concentrated inlets (e.g. swallow holes) or losing streams (Field 2006) and outlets (springs) (Goldscheider et al. 2008; Käss 1998; Lerch et al. 2005) if groundwater is not directly accessible through caves. A combination of short- and long-term tracer tests enables to define those flow paths that are activated in varying hydrological conditions (Göppert \& Goldscheider 2008). Especially in studies on vulnerability assessment of karst aquifers it can be extremely important to monitor potential outlets over at least one year in order to determine possible flow paths of contaminants in different hydrological conditions (Kogovšek and Petrič 2004, 2006).
Cave exploration is a valuable aid in studying karst aquifers, since discoveries of active caves allow direct observation of underground flow paths and enhance dye tracing experiments (Häuselmann et al. 2003; Smart, 1988; Staut \& Auersperger 2006; White 2007). Where surface drainage is particularly ephemeral, such as in South Mediterranean areas, the discovery of streams in caves makes it possible to carry out dye tracing tests during most of the year.

Recent explorations in Supramonte karst massif (Sardinia, Italy) have enabled speleologists to access active caves and find important underground rivers $(\mathrm{Ca}-$ bras et al. 2000; Crobu 2003; Crobu \& De Waele 2007; De Waele 2003). These key discoveries have allowed to organise several dye tests with sodium fluorescein (Uranine), placing charcoal bags deep in caves. This paper gives a summary of the present speleological and hydrological knowledge of this significant karst aquifer, describing all the dye tracing experiments in detail. This will help other researchers and hydrogeologists to make more reliable vulnerability maps based on updated speleological data often of difficult access to people not familiar with cave publications (Barrocu et al. 2007).

\section{GEOGRAPHICAL, GEOLOGICAL AND HYDROLOGICAL SYNTHESIS}

Supramonte is a karst massif located in the Central-Eastern part of the island and occupying an area of approximately $170 \mathrm{~km}^{2}$, almost $80 \%$ of which is composed of carbonate rocks (Sanna et al. 2002) (Fig. 1). It is characterised by an almost $1 \mathrm{~km}$ thick Middle Jurassic-Upper Cretaceous sequence composed of dolostones and limestones covering a crystalline Palaeozoic basement made out of granites and metamorphic rocks. The whole sequence has been folded and faulted during Tertiary displaying main N-S and NE-SW directions (Pasci 1997). The overall structure of karst massifs greatly influences the hydrogeological asset (Goldscheider 2005), and Supramonte is no exception.

Allogenic surface waters flowing from the Palaeozoic basement (altitude around $1400 \mathrm{~m}$ a.s.l.) are directed underground as soon as they reach the fractured basal dolostone formation, in the Southern part of Supramonte. Underground drainage follows the inclination of the bedrock close to the contact with the carbonate rocks, along major faults and axes of folds (synclines of Lanaitto, Flumineddu-Gorropu and Campu Oddeu-Or- bisi) showing a general direction from South to North. Towards the East and the West the carbonate aquifer is limited by the permeability threshold of the Palaeozoic basement located at higher altitudes (Sanna et al. 2002) (Fig. 2).

Thus, main inlets of the system are located in South Supramonte (see Fig. 3 for locations). S'Edera cave drains several small allogenic streamlets coming from the South and directs water underground towards the North. This cave represents the southernmost part of the main hydrological system. Water is not completely drained by S'Edera cave system during important floods and flows further to the North-East and is eventually swallowed in the Orbisi sinkhole. This cave is part of a smaller independent karst system comprising the Luigi Donini cave and the Giuseppe Sardu shaft and has its outlet probably at Gorropu spring, in the central eastern part of Supramonte. Since no dye tracing experiments have been carried out in this part of Supramonte, this smaller satellite system will not be discussed in this paper. 


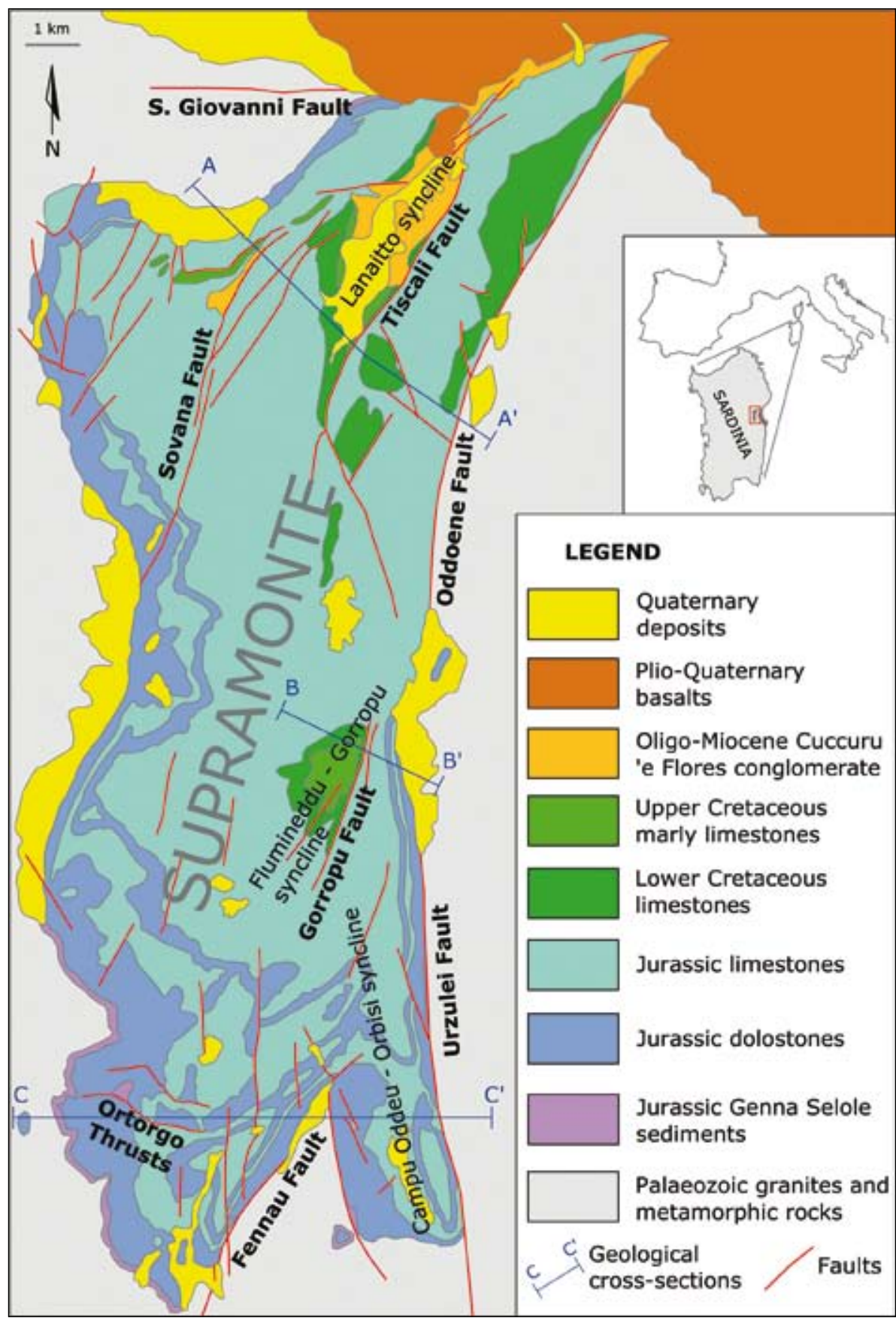

Fig. 1: Geological sketch map of Supramonte (modified from Pasci, 1997).
The biggest river of the area, Riu Flumineddu, is captured along its upstream course by several swallow holes, the most important of which is known under the name Sa Funga 'e S'Abba. Further downstream many other swallow holes are known and some of these give access to important caves discussed later in this article.

The main outlets of the karst system are located 20 $\mathrm{km}$ to the North of S'Edera cave, along the northern border of Supramonte. Here lithological and structural constraints force the subterranean water to flow out of the system though a series of springs. The most important of these are Su Gologone, Su Tippari and San Pantaleo, the first being captured for drinking water purposes, the other two almost permanently drowned by the artificial lake caused by the Pedra 'e Othoni dam, built on Cedrino river (De Waele 2008).

Before the discoveries of the last 10 years, water flowing in S'Edera cave was believed to exit at Gorropu spring (Assorgia et al. 1973). Geological and structural evidence does not rule out this possibility, but a connection between S'Edera cave and Lanaitto valley (and thus the northern springs) was retained highly probable (Sanna \& Vernier 1993).

\section{ACCESSIBLE UNDERGROUND DRAINAGE NETWORK}

More than 400 caves are known in Supramonte but only around $2 \%$ of these are characterised by the presence of important groundwater bodies. The most important of these caves are described below and their location is shown in Fig. 3. 


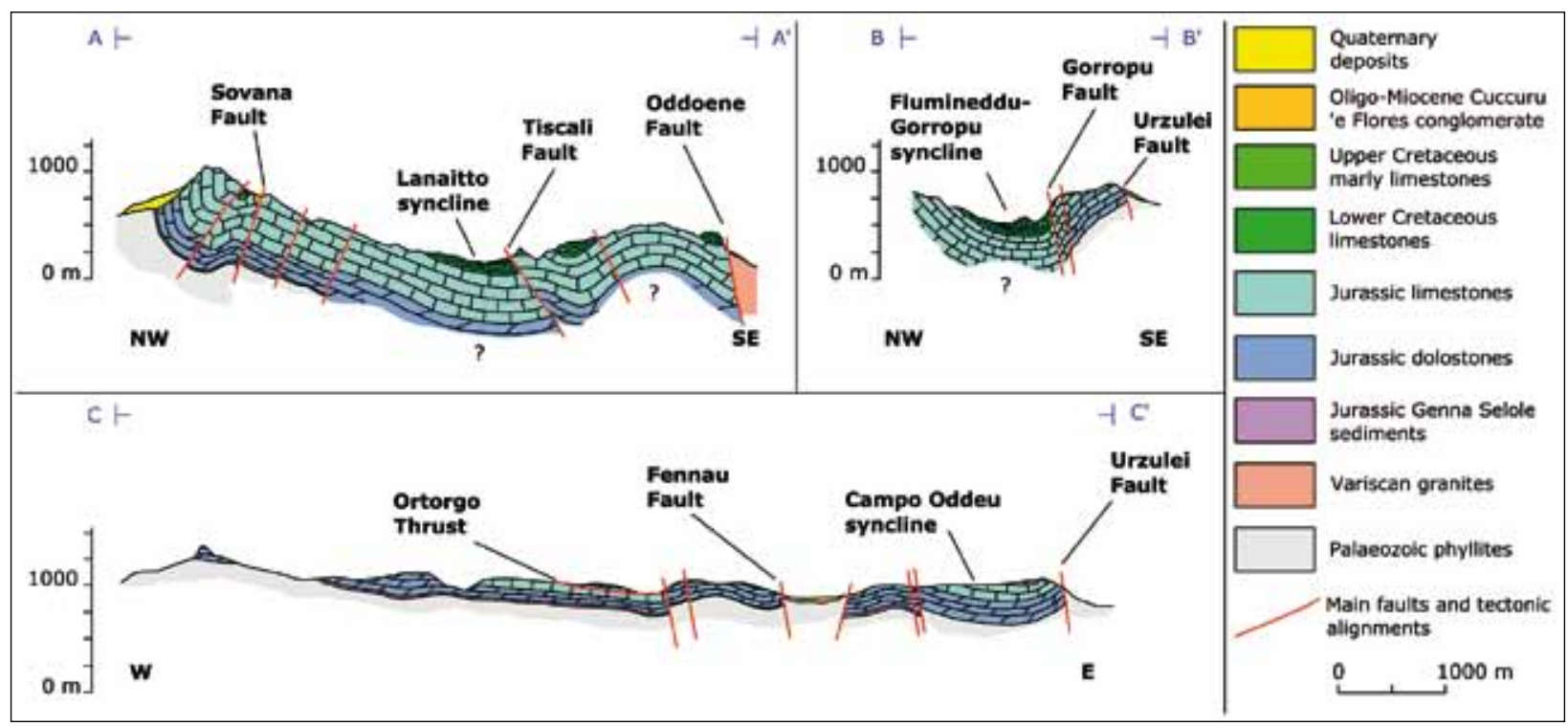

Fig. 2: Geological schematic cross-sections (geological profiles modified from Sanna et al. 2002); for location see Fig. 1.

\section{SHORT HISTORY OF EXPLORATIONS}

Systematic explorations started in Supramonte massif only relatively recently, with the Su Bentu-Sa Oche cave system (North-Supramonte) in the 50s (Columbu 1955) and the discovery and exploration of the first $3 \mathrm{~km}$ of Sa Rutta 'e S'Edera cave (South-Supramonte) in the final years of the 60s (Assorgia et al. 1973). Many cave associations of various nationalities have worked in the area, but without getting into the heart of the system. The major discoveries are related to: (a) Su Bentu-Sa Oche cave system, surveyed for around $15 \mathrm{~km}$ by the Gruppo Grotte Nuorese (Carta et al. 1988) and still object of exploration every year; (b) S'Edera cave, that doubled its development (from 3 to $6 \mathrm{~km}$ ) (Scano 2002); (c) the descent of many deep shafts, none of which however reached important active river parts (Fercia \& Pappacoda 1992). These earlier researchers thought that Supramonte was composed of two independent karst aquifers: S'Edera cave was believed to drain the southern part of the massif with the major spring at Gorropu gorge, while the bigger outlets located along the northern border of Supramonte ( $\mathrm{Su}$ Gologone, San Pantaleo springs) had their recharge in the surroundings of Lanaitto valley (Assorgia et al. 1973). This dogma was abandoned when a dye test carried out in 1999 (Bandiera 2000) unequivocally showed that Supramonte is a single karst aquifer, in which an enormous system of galleries and tunnels could be discovered. This has lead to an escalation of speleological explorations and surveys.

The first discovery of an underground river goes back to spring 1998, when cavers of the Gruppo Archeo Speleo Ambientale of Urzulei and Gruppo Speleo Am- bientale Sassari discover Sa Rutta ‘e Mandara 'e S’Uru Manna, 2,000 $\mathrm{m}$ of fissures, small shafts and galleries with an entrance $30 \mathrm{~m}$ above Flumineddu river bed, on the right side of the canyon (Cabras et al. 2000). Less than $1 \mathrm{~km}$ downstream, still on the right side of Flumineddu and $10 \mathrm{~m}$ above the river bed, another active cave, Su Colostrargiu, is discovered by independent cavers in 2000. This cave, after further exploration in 2006, is 1,500 meters long and ends in a boulder choke that abruptly blocks a river passage at a bit more than $150 \mathrm{~m}$ depth (Crobu 2003).

In autumn 2001, $2 \mathrm{~km}$ downstream Su Colostrargiu, still at the right side of the canyon but this time almost on the canyon floor (subject to flooding during winters) another important, but this time $340 \mathrm{~m}$ deep and 1,500 $\mathrm{m}$ long, cave is discovered and explored: S'Orale 'e $\mathrm{Su}$ Mudrecu (also called VPF) (Crobu 2003). During the winter of 2002, $1 \mathrm{~km}$ downstream VPF and only a few meters above the canyon floor, the most important cave entrance is found, Su Eni 'e Istettai, surveyed during 2003 up to a depth of $360 \mathrm{~m}$. Here a small underground river is followed up to a small sump, which is passed in apnea but gives access to a narrow gallery that apparently ends in a boulder choke (Crobu \& De Waele 2007). In the same summer several cavers operate inside S'Edera cave succeeding in passing the since 40 years unviolated final breakdown, discovering over $500 \mathrm{~m}$ of underground gallery up to a final sump that will later be explored by cave divers of the Federazione Speleologica Sarda (De Waele 2003; Tuveri \& Moi 2006). At the end of the summer, together with the cavers of the Groupe Ulysse Spéléo of Lyon, other $2 \mathrm{~km}$ of new conduits are discovered behind 


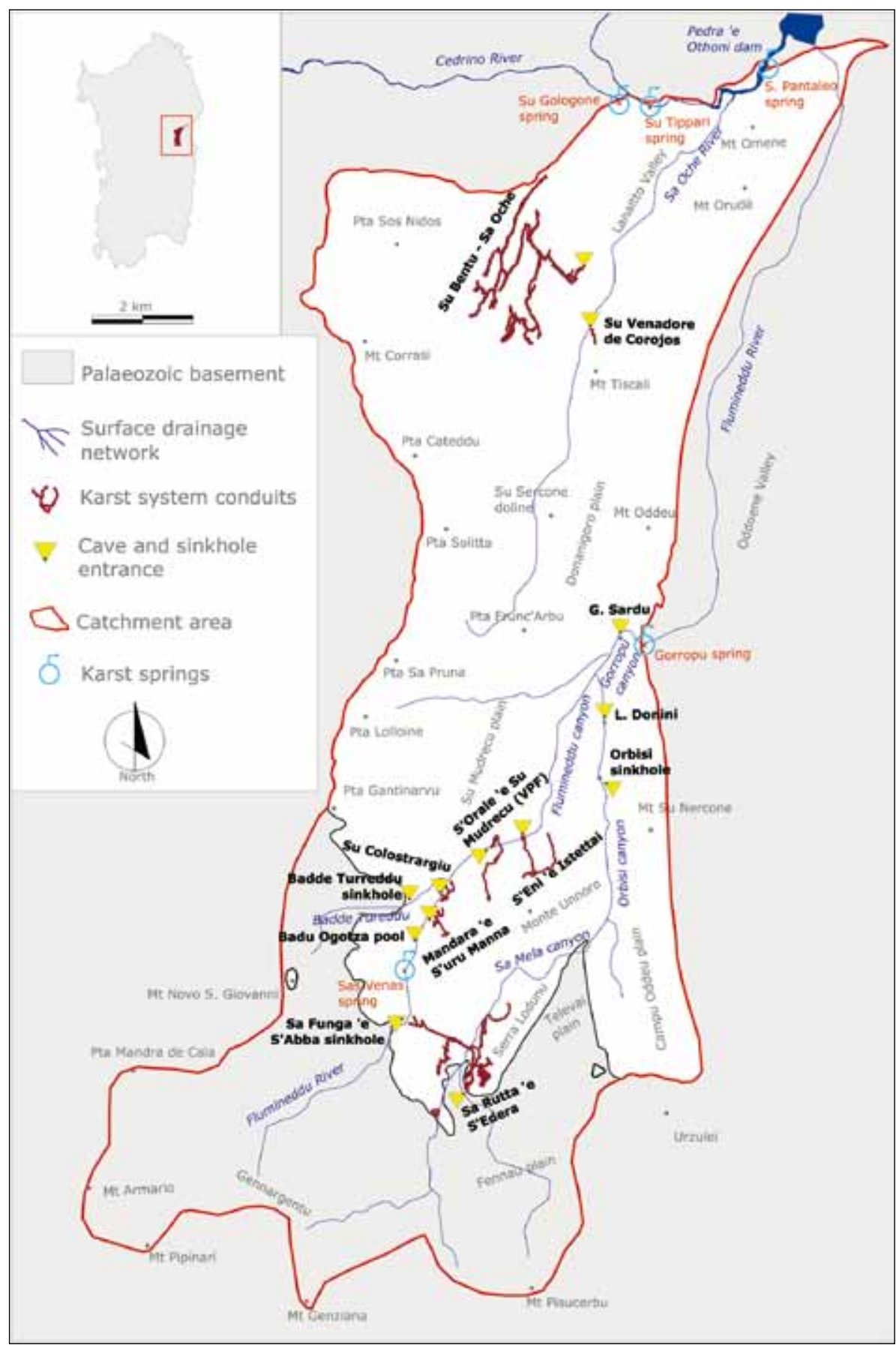

Fig. 3: Supramonte karst area with major caves and springs.

new passages making S’Edera longer than $13 \mathrm{~km}$ (De Waele et al. 2006).

Also at Istettai the main underground river of Supramonte is at last reached by Vittorio Crobu and Marcello Moi in September 2004, but another flood season obliges the explorers to wait several months again (Cossu et al. 2007). The following summer the explorers are able to descend this main river up to $450 \mathrm{~m}$ depth and during the summer of 2006 all explored passages are surveyed, totalling a development of $4200 \mathrm{~m}$ (Crobu \& De Waele 2007). After the December 2004 exceptional flash flood, in the southern part of Lanaitto valley a new temporary overflow is discovered in alluvial boulders. This cave, explored by cavers of the Speleo Club Oliena, consists in $200 \mathrm{~m}$ of phreatic galleries ending in a sump which could be a hypothetical access to an underground tributary of the $\mathrm{Su}$ Gologone spring. During the following years cave divers Diego Vacca, Sandro Tuveri and Luca Sgualdini explore 5 sumps surveying further 250 $\mathrm{m}$ of conduits and stopping in front of a boulder choke (Capra 2007).

The past two summers have been dedicated to S'Orale 'e Su Mudrecu (VPF) where, after exploration in apnea of two small sumps, 2 $\mathrm{km}$ of new and huge galleries are discovered and partially

the upstream Sa Funga 'e S'Abba sump in S'Edera cave. Cave divers Vincent Lignier and Sylvestre Condamin explore huge passages that are only partially surveyed due to lack of time. These passages will be thoroughly explored and surveyed the following summer by 6 cavers of the Groupe Ulysse Spéléo and Gruppo Speleo-Archeologico Giovanni Spano Cagliari, with other $2 \mathrm{~km}$ of surveyed up to another sump, behind which the cave continues with similar dimensions. At present the cave is around $4.6 \mathrm{~km}$ long (Associazione Speleologica Progetto Supramonte 2007; De Waele et al. 2008). 


\section{CAVE MORPHOLOGY AND HYDROLOGY}

Only some caves with a perennial subterranean water flow have been used for hydrological investigations using fluorescent dyes. These caves are here shortly described.

Sa Rutta 'e S'Edera is the main cave system explored for a total development of approximately $13 \mathrm{~km}$ (De Waele 2003; Tuveri \& Moi 2006). It has an entrance at $950 \mathrm{~m}$ a.s.l. and descends rapidly along enlarged fissures in dolostones for 50 meters where a small river (1-3 l/s in average) is encountered (Fig. 4a). This small rivulet meets a greater subterranean river at $760 \mathrm{~m}$ a.s.l. bringing water from the southeastern flank of Serra Lodunu and having an average flow of $20 \mathrm{l} / \mathrm{s}$. Three hundred meters downstream of this confluence another major inlet is encountered coming from the West. This tributary conveys water from the swallow holes in the Riu Flumineddu (Sa Funga 'e S'Abba, $892 \mathrm{~m}$ a.s.l.). From here on a unique river having a flow rate of $50 \mathrm{l} / \mathrm{s}$ in average is formed and continues for another $1,5 \mathrm{~km}$ without receiving further tributaries and forming several sumps, disappearing in the final sump at $740 \mathrm{~m}$ a.s.l.

Several entrances of active caves are located along the course of Riu Flumineddu. Sa Rutta 'e Mandara 'e S'Uru Manna cave is located at $870 \mathrm{~m}$ a.s.l., approximately $2 \mathrm{~km}$ downstream of Sa Funga 'e S'Abba swallow hole and 500 metres downstream of Badu Ogotza, a series of permanent pools fed by some small perennial springs and a brook (Sas Venas). This cave is entirely developed along fissures and bedding planes in dolostones. Water is found at $780 \mathrm{~m}$ a.s.l. on the contact with basal dolostones along Ortorgo Thrust and flows in a Southeast direction (Fig. 4b). The active part ends in a tunnel at $750 \mathrm{~m}$ a.s.l. with a final sump of difficult access and not yet explored. Average flow rate is around $0.7 \mathrm{l} / \mathrm{s}$ (Cabras et al. 2000; Sanna \& Cabras 2008).

$\mathrm{Su}$ Colostrargiu cave is located $700 \mathrm{~m}$ downstream at $825 \mathrm{~m}$ a.s.l., a little before the confluence between Riu Flumineddu and Badde Tureddu. This cave, entirely developed in dolostones, reaches the Palaeozoic basement at an altitude of $740 \mathrm{~m}$ a.s.l. where an underground river is found with an average flow rate of $5 \mathrm{l} / \mathrm{s}$ (Fig. 4c). This water comes from several swallow holes present along the course of Badde Tureddu, less than a $\mathrm{km}$ to the West. This river can be followed, with difficulty, for a length of around 500 meters where it disappears into a final boulder choke, at $673 \mathrm{~m}$ a.s.l. (De Waele et al. 2007).

Another important underground stream is found in the deep S'Orale 'e Su Mudrecu cave, that has its entrance two $\mathrm{km}$ downstream at $790 \mathrm{~m}$ a.s.l.. A river with an average flow rate of $4 \mathrm{l} / \mathrm{s}$ is encountered here at 470 $\mathrm{m}$ a.s.l. (Fig. 4d). This river disappears in small passages close to the contact between dolostones and Palaeozoic basement at $440 \mathrm{~m}$ a.s.l. and flows towards the North where no active caves are known. The water can also be followed upstream, passing two small sumps in apnea, for a total length of about $2 \mathrm{~km}$ up to a final sump, at an altitude of approximately $630 \mathrm{~m}$ a.s.l. (Crobu 2003). The provenance of this stream is still unknown. Recently it has been demonstrated that at least part of this water comes from Mandara 'e S'Uru Manna.

Su Eni 'e Istettai is the deepest cave of the region (and of the Island), located $1 \mathrm{~km}$ downstream of S'Orale 'e Su Mudrecu. Here a perennial small rivulet is found at $460 \mathrm{~m}$ a.s.l., and this small tributary meets with the major underground stream, after a technically difficult cave part, at approximately $400 \mathrm{~m}$ a.s.l. The main river can be followed for about 100 meters upstream, where it flows out of an impressive dolostone boulder choke. This water has been proved to come from S'Edera cave, located 300 metres higher and at a distance of around $3 \mathrm{~km}$. The river can be followed for $1.5 \mathrm{~km}$ downstream (Fig. 4e) up to the final boulder choke, at $310 \mathrm{~m}$ a.s.l. (Crobu \& De Waele 2007).

From this point northwards no active caves are known and subterranean water flow appears to concentrate at a depth from surface of at least 400-500 metres. Towards the North, the first caves in which important water flow is encountered are located around the Lanaitto syncline valley, at a distance of approximately $10 \mathrm{~km}$ from the final part of Istettai cave.

$\mathrm{Su}$ Venadore de Corojos cave is the lowest cave entrance in the Lanaitto valley (168 $\mathrm{m}$ a.s.l.). It is located near the important Su Bentu-Sa Oche karst system, on the other side of the valley, and is characterised by a sub-horizontal cylindrical conduit interrupted by small sumps with big scallops on the cave walls. It is $450 \mathrm{~m}$ long developing in South direction and is completely flooded for most of the year. This cave could represent an overflow of S'Edera - Su Gologone underground drainage system (Capra 2007).

The Su Bentu-Sa Oche cave system has been explored for more than $15 \mathrm{~km}$ (Carta et al. 1988; Murgia 2007) and is characterised by an underground canyon and several tunnels of considerable dimensions developed at approximately 130-150 m a.s.l. reaching several sumps around $105 \mathrm{~m}$ a.s.l.. All these sumps, where explored, give access to a network of phreatic passages (Murgia \& Fancello 2000). In normal conditions there is no water flowing in the system, but during floods the water level in the sumps rises more than 30 meters and starts flowing through the canyon leaving the system at the Sa Oche entrance, reaching flow rates exceeding $10 \mathrm{~m}^{3} / \mathrm{s}$.

The $\mathrm{Su}$ Gologone spring is the major and best known outlet of the Supramonte karst aquifer (Fig. 4f). Two other important springs (Su Tippari and San Pantaleo) are unfortunately almost permanently drowned by 

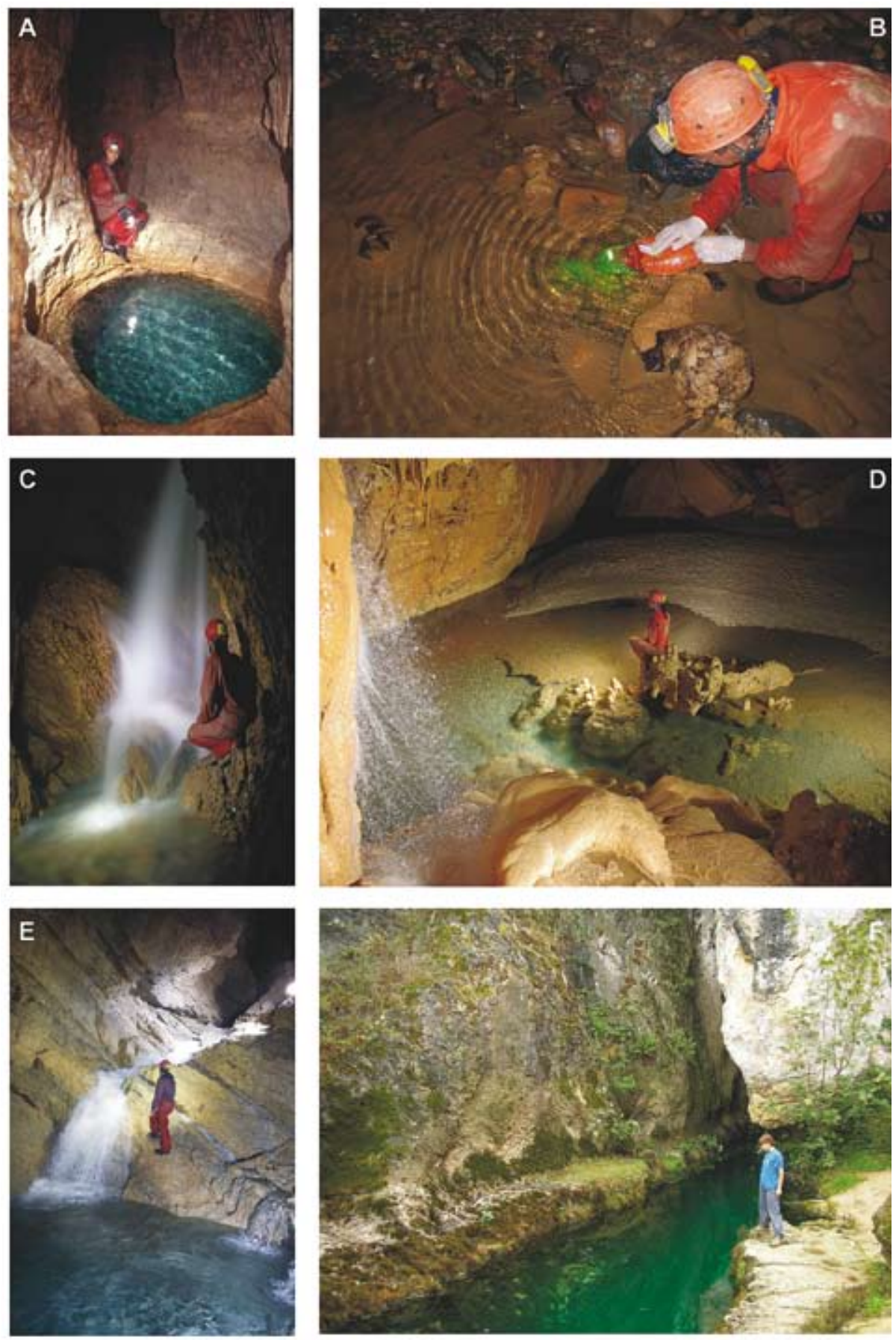

Fig. 4: Caves of hydrological importance: A. Pothole along the first streamlet encountered in S'Edera cave (Photo Riccardo De Luca); B. Injection of fluorescent dye in the small underground river of Mandara 'e S'Uru Manna (Photo Laura Sanna); C. Waterfall along the stream in $\mathrm{Su} \mathrm{Co}$ lostrargiu cave (Photo Vittorio Crobu); D. Waterfall and lake in the Atollo Room in S'Orale 'e Su Mudrecu Cave (Photo Vittorio Crobu); E. Waterfalls and rapids along the main collector stream in S'Eni 'e Istettai cave (Photo Vittorio Crobu); F. Su Gologone spring showing greenish fluorescent dye after the tracing experiment carried out in September 2007 (Photo Laura Sanna). the water of the Pedra 'e Othoni dam built on the Cedrino river some $\mathrm{km}$ downstream of $\mathrm{Su}$ Gologone. The same Su Gologone spring is subjected to flooding once or twice a year, when heavy rainfalls fill the reservoir too rapidly to allow water to flow out of it, rising the water level in the artificial lake (De Waele 2008). Su Gologone is located at $104 \mathrm{~m}$ a.s.l. and has been explored by Ol- ivier Isler up to a depth of $107 \mathrm{~m}$, thus going $3 \mathrm{~m}$ below sea level (Fancello 1997). Its mean minimum outflow is around $100 \mathrm{l} / \mathrm{s}$ with peak discharges during floods that exceed $10 \mathrm{~m}^{3} / \mathrm{s}$ (Sanna 1995). 


\section{DYE TRACING EXPERIMENTS}

Since the two first dye tracing experiments of 1967 and 1969 , in the past 10 years a total of 8 more dye injections have been carried out in recently discovered caves with underground streams. These experiments with their injections points and monitored caves and springs are shown in Fig. 5.

\section{JULY 1967}

In the summer of 1967 the earliest cave explorers of Sa Rutta 'e S'Edera carried out a dye trace experiment dissolving $3 \mathrm{~kg}$ of Methylene Blue in water disappearing in the Funga 'e S'Abba swallow hole. In the western branch of S'Edera cave from which a large amount of water comes, $\mathrm{pH}$ analysis gave positive results after 12 hours, indicating a possible connection between these two points (Assorgia et al. 1973).

\section{AUGUST 1969}

To ascertain this connection, this time using a more reliable method, two summers later the same tracing experiment was repeated using $4 \mathrm{~kg}$ of fluorescent dye Uranine injected in Sa Funga 'e S'Abba swallow hole and installing charcoal detectors at S'Edera cave, Gorropu spring and Su Gologone spring. Only S'Edera cave was positive after 18 hours, while the dye wasn't traced at both springs also after further injection of other $5 \mathrm{~kg}$ of dye (Assorgia et al. 1973).

\section{JUNE-SEPTEMBER 1999}

After 30 years cavers of the Gruppo Archeo Speleo Ambientale Urzulei and Gruppo Speleo Ambientale Sassari injected $10 \mathrm{~kg}$ of Uranine in S'Edera cave, downstream of the Funga 'e S'Abba confluence. Flow rate at

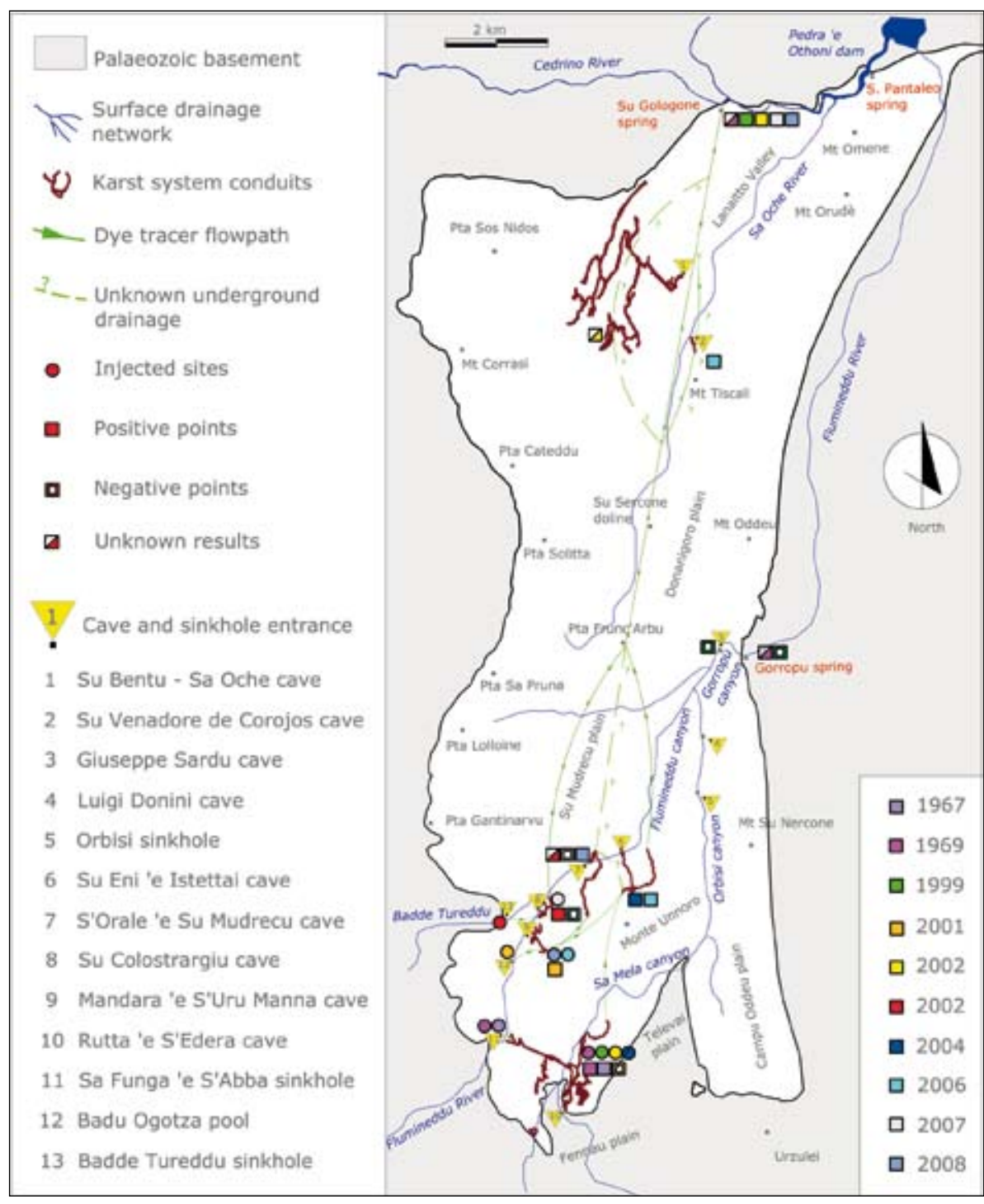

time of release was estimated in $60 \mathrm{l} / \mathrm{s}$. The charcoal detectors were placed at Gorropu and $\mathrm{Su}$ Gologone springs and in the final lake of a cave $1 \mathrm{~km}$ upstream Gorropu (Giuseppe Sardu cave). The dye was visible at $\mathrm{Su}$ Gologone at naked eye approximately 70 days after the injection, confirmed also by positivity of charcoal detectors, while all other monitored points were negative for the following 2 months (Bandiera 2000).

\section{NOVEMBER 2001}

In the early winter of 2001 a dye trace experiment was carried out in the upstream part of Flumineddu river. One kg of Uranine was dissolved at Badu Ogotza swallow hole putting charcoal detectors inside Mandara 'e S'Uru Manna cave and S’Edera cave (downstream confluence with Funga 'e S'Abba tributary). The un-

Fig. 5: Map showing certain and presumed hydrological connections between caves and springs. 


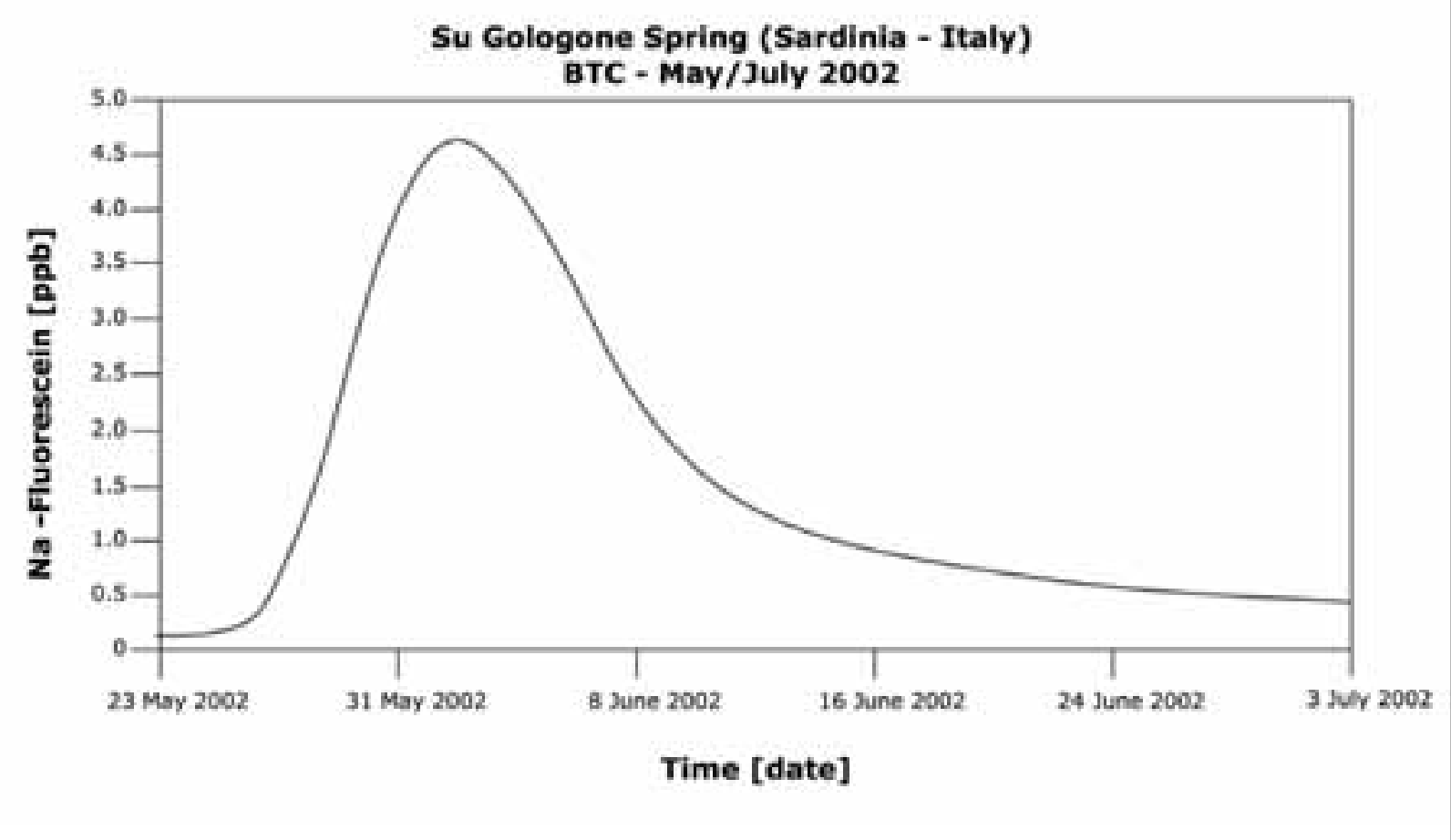

Fig. 6: Breakthrough Curve registered at Su Gologone spring during the 2002 tracer test (modified from Cabras et al. 2002).

derground stream of Mandara 'e S’Uru Manna was positive after 14 days, while S'Edera cave remained negative for two months (Crobu \& De Waele 2007).

\section{MAY-JULY 2002}

The dye tracing experiment of 1999 has been repeated by the Sardinian Federation of Speleologists with a smaller quantity of Uranine $(5 \mathrm{~kg}$ ) and monitoring $\mathrm{Su}$ Gologone spring with a G-GUN fluorimeter (Politecnico di Torino) from the end of May to 7 July making measurements every 4 minutes (almost 15,000 analysis). The dye was released the 1st of May in S'Edera cave with an estimated river flowrate of $120 \mathrm{l} / \mathrm{s}$. In this experiment also the final sump of Su Bentu cave has been equipped with charcoal detectors. The dye tracer has only been clearly registered at $\mathrm{Su}$ Gologone spring, the fluorimeter revealing fluorescein on May $26^{\text {th }}$ reaching maximum value of $4.5 \mathrm{ppb}$ one week later (between June $2^{\text {nd }}$ and $\left.4^{\text {th }}\right)$ followed by a slow decrease with concentration of 0.5 ppb on July $7^{\text {th }}$, when the monitoring was ended (Fig. 6). Minimum fluorescein transit time can be estimated in 26 days with an average flow velocity of $33 \mathrm{~m} / \mathrm{h}$, mean transit time instead is 34 days giving an average velocity of $27 \mathrm{~m} / \mathrm{h}$. The total amount of fluorescein discharged at the spring, estimated on the basis of the restitution graph and the flow rate during time of monitoring (ranging between 400-500 l/s), was $2.5 \mathrm{~kg}$ (Cabras et al. 2002), demonstrating that part of the dye was withheld in the aquifer or discharged in other springs, like the ones submerged by the artificial lake of Cedrino (De Waele 2008). The slightly positive charcoal detector collected at $\mathrm{Su}$ Bentu could indicate arrival through diffusion of Uranine, but this result is retained not truly reliable.

\section{SEPTEMBER 2002}

Another small dye tracing experiment has been carried out with $1 \mathrm{~kg}$ of Uranine in the autumn between some swallow holes along Badde Tureddu and Su Colostrargiu and S'Orale 'e Su Mudrecu caves. The fluorescent dye was clearly visible at naked eye in Su Colostrargiu cave 8 days after injection (Crobu \& De Waele 2007) and was also retraced in the charcoal detector taken from S'Orale 'e Su Mudrecu several months later. The connection between Badde Tureddu sinks and Su Colostrargiu is unmistakably proved, but that between the two caves, nevertheless, is unreliable since around 10 days after dye injection the surface drainage network activated due to heavy rainfall, and remaining Uranine could probably have been brought to S'Orale 'e Su Mudrecu along Riu Flumineddu.

\section{SEPTEMBER 2004}

With the discovery of the river at Su Eni 'e Istettai in September 2004, a dye tracing experiment was immediately set up to ascertain that this river is effectively the same disappearing in the final sump at S'Edera cave. 
Two $\mathrm{kg}$ of Uranine dye were injected downstream the Funga 'e S'Abba tributary in S'Edera cave and appeared only twelve days later in Istettai, visible at naked eye. This result designates the main underground water flow in South Supramonte (Crobu \& De Waele 2007).

\section{JULY 2006}

The connection between S'Edera and Istettai didn't give an answer to the most important question about the direction of rivers flowing in Mandara 'e S'Uru Manna, $\mathrm{Su}$ Colostrargiu and S'Orale 'e Su Mudrecu. The first indications arrived from a dye tracing experiment carried out with $1 \mathrm{~kg}$ of Uranine at Mandara 'e S'Uru Manna cave in the summer of 2006. Charcoal detectors were placed inside Su Eni 'e Istettai, Su Colostrargiu and Su Venadore de Corojos caves. After 14 days charcoal detectors were positive at Istettai, while the dye has not been registered inside Colostrargiu. At Su Venadore de Corojos, instead, the charcoal detector sampled several months after the test also gave a positive result. Thus, water infiltrating at Badu Ogotza pools transits in Mandara 'e S'Uru Manna cave and, following unknown underground paths, appears in Istettai's river (Sanna \& Cabras 2008). Su Venadore de Corojos cave seems to be located close to and in contact with at least one of the underground flow paths from Istettai to Su Gologone.

\section{JULY-SEPTEMBER 2007}

The second answer arrived with the injection of $2 \mathrm{~kg}$ Uranine in Su Colostrargiu cave and the installa- tion of charcoal detectors in S'Orale 'e Su Mudrecu cave and at $\mathrm{Su}$ Gologone spring. The charcoal bag in the cave remained negative for three months, while Su Gologone spring, located $13 \mathrm{~km}$ South, started releasing the fluorescent dye approximately 56 days after injection. This resolves our doubts on the positive results obtained during the September 2002 test and definitively proofs that Su Colostrargiu and S'Orale 'e Su Mudrecu streams are independent and are tributaries of the main underground stream connecting S'Edera and Istettai having their confluence downstream, beyond the final boulder choke of Su Eni 'e Istettai (De Waele et al. 2008; Sanna \& Cabras 2008).

\section{JULY-AUGUST 2008}

The most recent dye tracing test has been carried out at Mandara 'e S'Uru Manna cave, with the injection of $0.9 \mathrm{~kg}$ of Uranine and the monitoring of S'Orale 'e Su Mudrecu underground stream and Su Gologone spring. After about 20 days, the fluorescent dye was visible at naked eye inside the cave and about one month later also in the charcoal detector placed at the spring. This result, however, still doesn't clarify the relationship between S'Orale 'e Su Mudrecu and Su Eni 'e Istettai cave. It is however clear that the small streamlet of Mandara 'e S'Uru Manna cave feeds both cave rivers (this is the first case of diffluence in Sardinia). Water flowing in S'Orale 'e Su Mudrecu cave, instead, reaches Su Gologone without passing Istettai, directing southwards through downstream unknown passages.

\section{SUMMARY AND DISCUSSION}

The discovery of cave systems with underground water flows has allowed to carry out a series of dye tracing experiments with the aim of defining the subterranean drainage divides and the connections between caves and water flows. Before the discovery of these caves water was thought to flow from S'Edera cave to the nearest Gorropu spring, although tracing experiments carried out in 1967 and 1969 did not give positive results. With the dye tracing experiment of 1999 all doubts were cancelled, and a segment of this $20 \mathrm{~km}$ long underground route has been discovered in Istettai cave as demonstrated by the 2004 dye test.

All these dye tracing experiments, especially those carried out in several newly discovered caves, have enabled to draw the following conclusions (Fig. 7): (1) water of Riu Flumineddu entering in the upstream Sa Funga 'e S'Abba swallow hole enters S'Edera cave and confluences with the main underground river of S'Edera at approximately $1 \mathrm{~km}$ of the entrance; (2) water sinking at S'Edera cave combines with the Sa Funga 'e S'Abba tributary, disappears in the final sump at $1.5 \mathrm{~km}$ from the entrance, flows along unknown paths under Monte Unnoro, through Istettai cave and finally disappears in the terminal boulder choke in northward direction; (3) the Badu Ogotza pools, $2 \mathrm{~km}$ downstream of Sa Funga 'e S'Abba swallow hole, drain water towards Mandara 'e S’Uru Manna cave, disappearing in its final sump at 500 $\mathrm{m}$ from entrance and joining, along unexplored underground paths, the rivers flowing through Istettai and S'Orale 'e Su Mudrecu caves; (4) the Badde Tureddu sinkholes carry water into $\mathrm{Su}$ Colostrargiu cave, where it can be followed for 500 meters to the final choke, from where it continues along unknown routes in northward direction reaching $\mathrm{Su}$ Gologone spring; (5) the river 


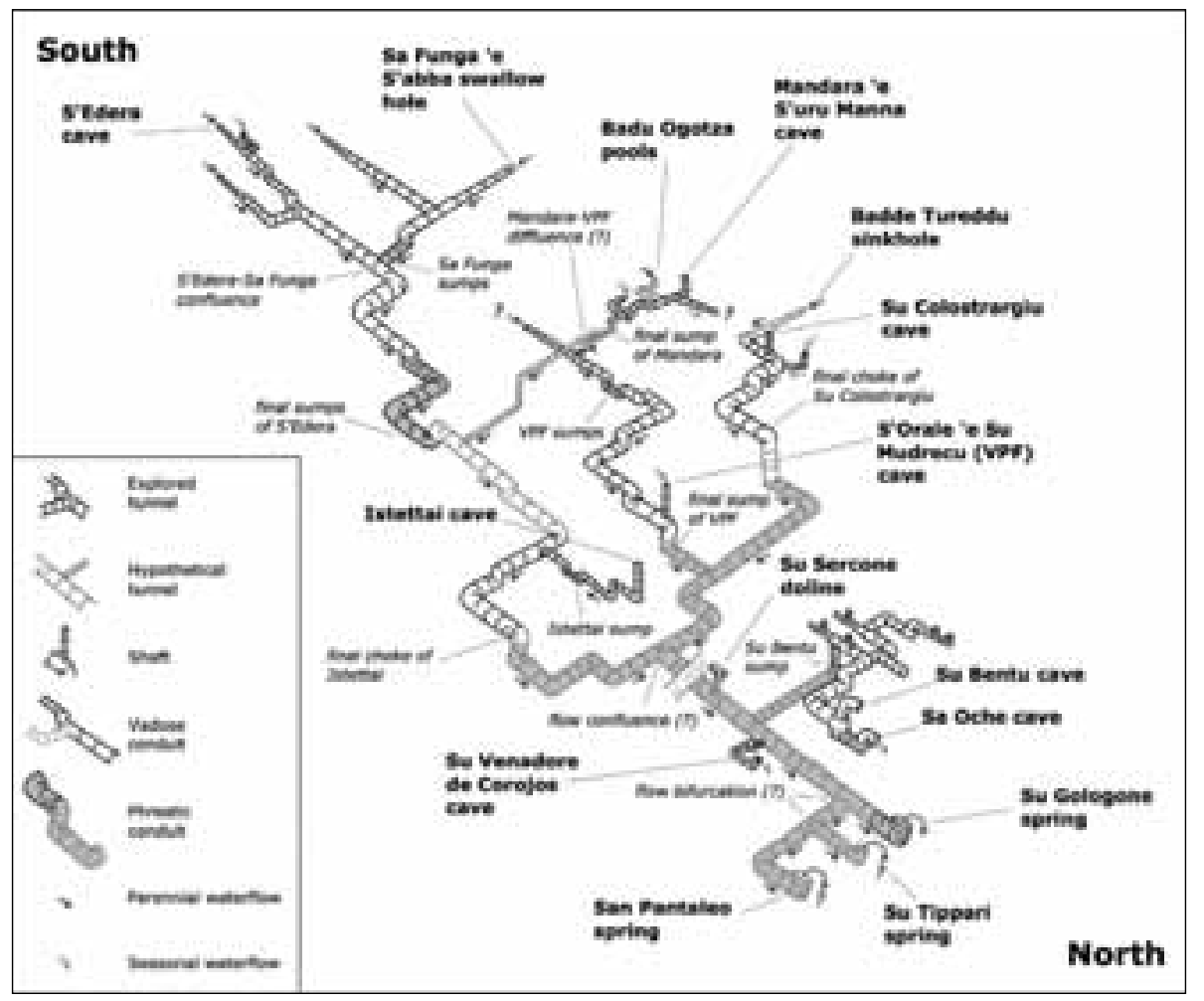

Fig. 7: Pipe diagram of the Supramonte active conduit flow system based on hydrological and direct observations (not to scale).

northward direction with unknown destination towards Su Gologone spring; (6) fluorescent dyes can be detected in the downstream caves around Lanaitto Valley only through diffusion, since all these caves reach the karst water table but no important currents are observed.

In the near future a dye tracer experiment is programmed in S'Orale 'e $\mathrm{Su}$ Mudrecu cave, and continuous monitoring of the $\mathrm{Su}$ Eni 'e Istettai cave and the $\mathrm{Su}$ Gologone spring is being carried out. Further speleo-

discovered inside S'Orale 'e Su Mudrecu has partially unknown origin (from the South, a minor part coming from Mandara 'e S'Uru Manna cave) and disappears in logical explorations will also help us in understanding more about this continuously evolving underground landscape.

Table 1: Tracing experiments carried out in Supramonte since 1967.

\begin{tabular}{|c|c|c|c|c|c|}
\hline Year & Dye injection in & $\begin{array}{l}\text { Amount and name of } \\
\text { dye injected }\end{array}$ & Charcoal detector in & Dye results & \begin{tabular}{|l|} 
Mean \\
transit \\
time
\end{tabular} \\
\hline 1967 & Sa Funga 'e S'Abba Sinkhole & $3 \mathrm{Kg}$ Methylene Blue & Sa Rutta'e S'Edera Cave & Positive & $12 \mathrm{~h}$ \\
\hline 1969 & $\begin{array}{l}\text { Sa Funga 'e S'Abba Sinkhole } \\
\text { Sa Rutta 'e S'Edera Cave }\end{array}$ & $\begin{array}{l}4 \mathrm{Kg} \mathrm{Na} \text {-Fluorescein } \\
5 \mathrm{Kg} \mathrm{Na} \text {-Fluorescein }\end{array}$ & $\begin{array}{l}\text { Sa Rutta 'e S'Edera Cave } \\
\text { Su Gologone Spring } \\
\text { Gorropu Spring }\end{array}$ & $\begin{array}{l}\text { Positive } \\
\text { Unknown } \\
\text { Unknown }\end{array}$ & $18 \mathrm{~h}$ \\
\hline 1999 & Sa Rutta 'e S'Edera Cave & $10 \mathrm{Kg} \mathrm{Na}$-Fluorescein & $\begin{array}{l}\text { Su Gologone Spring } \\
\text { Gorropu Spring } \\
\text { G. Sardu Cave }\end{array}$ & \begin{tabular}{|l|} 
Positive \\
Negative \\
Negative \\
\end{tabular} & 70 days \\
\hline 2001 & Badu Ogotza Pools & $1 \mathrm{Kg} \mathrm{Na}$-Fluorescein & $\begin{array}{l}\text { Mandara'e S'uru Manna Cave } \\
\text { Sa Rutta'e S'Edera Cave }\end{array}$ & $\begin{array}{l}\text { Positive } \\
\text { Negative }\end{array}$ & 14 days \\
\hline 2002 & Sa Rutta 'e S'Edera Cave & $5 \mathrm{Kg} \mathrm{Na}$-Fluorescein & $\begin{array}{l}\text { Su Gologone Spring } \\
\text { Su Bentu Cave }\end{array}$ & \begin{tabular}{|l|} 
Positive \\
Doubtful \\
\end{tabular} & 34 days \\
\hline 2002 & Badde Tureddu Sinkhole & $1 \mathrm{Kg} \mathrm{Na}$-Fluorescein & $\begin{array}{l}\text { Su Colostrargiu Cave } \\
\text { S'Orale'e Su Mudrecu Cave }\end{array}$ & \begin{tabular}{|l|} 
Positive \\
Doubtful
\end{tabular} & 8 days \\
\hline 2004 & Sa Rutta 'e S'Edera Cave & $2 \mathrm{Kg} \mathrm{Na}$-Fluorescein & S'Eni'e Istettai Cave & Positive & 12 days \\
\hline 2006 & Mandara 'e S'uru Manna Cave & $1 \mathrm{Kg} \mathrm{Na}$-Fluorescein & $\begin{array}{l}\text { S'Eni'e Istettai Cave } \\
\text { Su Venadore de Corojos Cave } \\
\text { Su Colostrargiu Cave }\end{array}$ & \begin{tabular}{|l|} 
Positive \\
Positive \\
Negative \\
\end{tabular} & $\begin{array}{l}14 \text { days } \\
\text { Unknown }\end{array}$ \\
\hline 2007 & Su Colostrargiu Cave & $2 \mathrm{Kg} \mathrm{Na}$-Fluorescein & $\begin{array}{l}\text { Su Gologone Spring } \\
\text { S'Orale'e Su Mudrecu Cave }\end{array}$ & $\begin{array}{l}\text { Positive } \\
\text { Negative }\end{array}$ & 56 days \\
\hline 2008 & Mandara 'e S'uru Manna Cave & 0,9 Kg Na-Fluorescein & $\begin{array}{l}\text { S'Orale 'e Su Mudrecu Cave } \\
\text { Su Gologone Spring }\end{array}$ & \begin{tabular}{|l} 
Positive \\
Positive
\end{tabular} & $\begin{array}{l}20 \text { days } \\
50 \text { days }\end{array}$ \\
\hline
\end{tabular}




\section{ACKNOWLEDGEMENTS}

We would like to thank all cavers that have substantially helped during all the phases of these 10 years, and especially Silvia Arrica, Carla Corongiu, Vittorio Crobu, Riccardo De Luca, Massimo Farris, Gianluca Melis, Marcello Moi, Antonio Saba, the French cavers of the Groupe Ulysse Spéléo Lyon and many other cavers of the Sardinian Federation of Speleologists that have sporadically accompanied us during our explorations. Special thanks to Franco Bandiera of Gruppo Speleo Ambientale Sassari for the supply of fluorescein salt in several tracing experiments, to Prof. Bartolomeo Vigna of the Polytechnic University of Turin for the borrowing of the fluorimeter used in the 2002 dye tracing test and to Mauro Mucedda of University of Sassari and Alessandro Uggeri of Idrogea Varese for the charcoal detector analyses. Also comments of Nico Goldscheider and an anonymous reviewer have been greatly appreciated.

\section{REFERENCES}

Andreo, B., ed., 2008: Karst hydrogeology in caves.- International Journal of Speleology, Special Issue, 37 (1), $82 \mathrm{p}$.

Associazione Speleologica Progetto Supramonte, 2007: Le grandiose gallerie del VPF.- Speleologia, 57, 7071.

Assorgia, A., P. Biondi \& A. Morisi, 1973: Aspetti geomorfologici sul Supramonte di Urzulei (Nuoro, Sardegna centro-orientale).- Rassegna Speleologica Italiana, 25, 139-167.

Bakalowicz, M., 2005: Karst groundwater: a challenge for new resources.- Hydrogeology Journal, 13, 148160 .

Bandiera, F., 2000: Colorazione con fluoresceina del sistema idrico sotterraneo di Sa Rutta 'e S’Edera-Su Gologone.- Sardegna Speleologica, 16, 2-8.

Barrocu, G., M. Muzzu \& G. Uras, 2007: Hydrogeology and vulnerability map (Epik method) of the "Supramonte" karstic system, north-central Sardinia.- Environmental Geology, 51, 701-706.

Birk, S., R. Liedl \& M. Sauter, 2004: Identification of localised recharge and conduit flow by combined analysis of hydraulic and physico-chemical spring responses (Urenbrunnen, SW-Germany).- Journal of Hydrology, 286, 179-193.

Cabras, S., S. Cabras, Q. Mulas, L. Sanna, A. Cossu \& D. Soro, 2000: Sa Rutta 'e Mandara 'e S’Uru Manna.Sardegna Speleologica, 16, 17-27.

Cabras, S., F. Murgia \& L. Sanna, 2002: Complesso S'Edera-Su Gologone: tracciamento geochimico sulle acque sotterranee del Supramonte.- Sardegna Speleologica, 19, 18-24.

Capra, M., 2007: La grotta "Su Venadore de Corojos": fotoracconto.- III Radino Speleologico Regionale della Sardegna, Urzulei 25-27 aprile 2008.
Carta, G., F. Murgia \& F. Sanna, 1988: $4^{\circ}$ Vento: nuovo complesso di diramazioni nella Grotta di "Su Bentu".- Gruttas e Nurras, 1-8.

Columbu, M., 1955: Note su alcune grotte della provincia di Nuoro.- Rassegna Speleologica Italiana, 7, 139-149.

Cossu, A., J. De Waele \& F. Di Gregorio, 2007: Coastal karst geomorphosites at risk? A case study: the floods of 6-11 December 2004 in Central-East Sardinia, in Parise, M. \& J. Gunn, eds., Natural and Anthropogenic Hazards in Karst Areas: Recognition, Analysis and Mitigation.- Geological Society of London, Special Publication, 279: London, Geological Society of London, p. 85-95.

Crobu, V., 2003: Supramonte verticale.- Speleologia, 48, 34-51.

Crobu, V. \& J. De Waele, 2007: Nel Supramonte profondo. Le esplorazioni in Su Eni 'e Istettai.- Speleologia, $56,12-27$.

Daly, D., A. Dassargues, D. Drew, S. Dunne, N. Goldscheider, S. Neale, I. C. Popescu \& F. Zwahlen, 2002: Main concepts of the "European approach" to karstgroundwater-vulnerability assessment and mapping.- Hydrogeology Journal, 10, 340-345.

De Waele, J., 2003: La nuova era di S’Edera.- Speleologia, 48, 12-33.

De Waele, J., 2008: Interaction between a dam site and karst springs: the case of Supramonte (Central-East Sardinia, Italy).- Engineering Geology, 99, 128-137.

De Waele, J., C. Corongiu, L. Sanna, V. Crobu, R. De Luca, S. Arrica, G. Melis, P. Marcia, M. Moi, S. Cabras \& A. Saba, 2007: Su Colostrargiu, un fiume di passione.- Anthèo 9, (in print). 
De Waele, J., L. Mereu, G. Bost \& Y. Robin, 2006: Sa Rutta 'e S'Edera (Sardaigne centre-orientale): exploration post-siphon de l'affluent E.T.I. (E’ Terra Incognita) du 23 au 25 juillet 2004.- Spéléo-Dossiers, 35, 107 121.

De Waele, J., Y. Robin \& L. Sanna, 2008: Ten years of explorations in South Supramonte (Sardinia).- Proceedings of the IVth European Speleological Congress "Vercors 2008", 299-302.

Desmarais, K. \& S. Rojstaczer, 2002: Inferring source waters from measurements of carbonate spring response to storms.- Journal of Hydrology, 260, 118 134.

Fancello, L., 1997: Raggiunto il fondo: -107 metri a Su Gologone !- Sardegna Speleologica, 12, 29-32.

Fercia, S. \& M. Pappacoda, 1992: In attesa del colpo grosso.- Speleologia, 27, 22-31.

Field, M. S., 2006: Tracer-Test design for losing streamaquifer systems.- International Journal of Speleology, 35, 25-36.

Gabrovšek, F., W. Dreybrodt \& D. Romanov, 2005: Processes of Speleogenesis: a modelling approach.: Ljubljana, Slovenia, $376 \mathrm{p}$.

Gabrovšek, F., D. Romanov \& W. Dreybrodt, 2004: Early karstification in a dual-fracture aquifer: the role of exchange flow between prominent fractures and a dense net of fissures.- Journal of Hydrology, 299, 45-66.

Goldscheider, N., 2005: Karst groundwater vulnerability mapping - application of a new method in the Swabian Alb, Germany.- Hydrogeology Journal, 13, 555-564.

Goldscheider, N. \& D. Drew, 2007: Methods in Karst Hydrogeology.- International Contributions to Hydrogeology: London, Taylor \& Francis, 264 p.

Goldscheider, N., J. Meiman, M. Pronk \& C. Smart, 2008: Tracer tests in karst hydrogeology and speleology.International Journal of Speleology, 37, 27-40.

Göppert, N. \& N. Goldscheider, 2008: Solute and colloid transport in karst conduits under low- and highflow conditions.- Ground Water, 46, 61-68.

Häuselmann, P., M. Otz \& P.-Y. Jeannin, 2003: A review of the dye tracing experiments done in the Siebenhengste karst region (Bern, Switzerland).- Eclogae Geologicae Helvetiae, 96, 23-36.

Käss, W., 1998: Tracing technique in Geohydrology.: Rotterdam, Balkema A.A., 332 p.

Kogovšek, J. \& M. Petrič, 2004: Advantages of longerterm tracing - three case studies from Slovenia.Environmental Geology, 47, 76-83.
Kogovšek, J. \& M. Petrič, 2006: Tracer test on the Mala Gora landfill near Ribnica in South-Eastern Slovenia.- Acta Carsologica, 35, 91-101.

Labat, D., A. Mangin \& R. Abadou, 2002: Rainfall-runoff relations for karstic springs: multifractal analysis.Journal of Hydrology, 256, 176-195.

Lerch, R. N., C. M. Wicks \& P. L. Moss, 2005: Hydrologic Characterization of Two Karst Recharge Areas in Boone County, Missouri.- Journal of Cave and Karst Studies, 67, 158-173.

Murgia, F., 2007: Sentieri di buio nel cuorz del Supramonte.- Darwin Quaderni, 3, 28-41.

Murgia, F. \& L. Fancello, 2000: Su Bentu 2000: nel cuore del sistema.- Sardegna Speleologica, 17, 3-9.

Pasci, S., 1997: Tertiary transcurrent tectonics of NorthCentral Sardinia.- Bulletin de la Société Géologique de France, 168, 301-312.

Perrin, J., A. Pochon, P.-Y. Jeannin \& F. Zwahlen, 2004: Vulnerability assessment in karstic areas: validation by field experiments.- Environmental Geology, 46, 237-245.

Prelovšek, M., J. Turk \& F. Gabrovšek, 2008: Hydrodynamic aspect of caves.- International Journal of Speleology, 37, 11-26.

Pulido Bosch, A., 2001: Investigation and exploration of karstic aquifers.- Boletin Geologico y Minero, 112, 65-76.

Sanna, F., 1995: Individuazione di importanti riserve idriche strategiche nel Supramonte di Oliena-Orgosolo-Urzulei (Sardegna centro-orientale).- PhD thesis, Politecnico di Torino \& University of Cagliari, Cagliari, $212 \mathrm{p}$.

Sanna, F. \& A. Vernier, 1993: Studio preliminare sull'assetto geo-strutturale ed idrogeologico del "Supramonte" di Oliena-Orgosolo-Urzulei (Sardegna centro-orientale).- Geologia Applicata e Idrogeologia, 28, 645-653.

Sanna, F., A. Vernier \& B. Vigna, 2002: Le sorgenti di $\mathrm{Su}$ Gologone nel contesto della idrostruttura carbonatica del Supramonte: rapporti tra carsismo ed idrogeologia.- Atti del Convegno "Il carsismo e la ricerca speleologica in Sardegna", 29-46.

Sanna, L. \& S. Cabras, 2008: Recente colorazione con fluoresceina delle acque sotterranee nel Supramonte di Urzulei (Sardegna).- XX Congresso Nazionale di Speleologia.

Scano, A., 2002: Esplorazioni nel Complesso di "Sa Rutta ‘e S’Edera” (Urzulei, Sardegna centro-orientale).Convegno di Studio "Il Carsismo e la Ricerca Speleologica in Sardegna”, Anthèo, 6, 201-218.

Smart, C., 1988: Artificial tracer techniques for the determination of the structure of conduit aquifers.Ground Water, 26, 445-453. 
Staut, M. \& P. Auersperger, 2006: Tracing of the stream flowing through the cave Ferranova Buža, Central Slovenia.- Acta Carsologica, 35, 83-89.

Tuveri, A. \& M. Moi, 2006: S'Edera 2005.- Sardegna Speleologica, 23, 20-22.
White, W. B., 2002: Karst hydrology: recent developments and open questions.- Engineering Geology, 65, 85-105.

White, W. B., 2007: A brief history of karst hydrogeology: contributions of the NSS.- Journal of Cave and Karst Studies, 69, 13-26. 